\title{
Leukocyte-Platelet Interaction
}

\section{RELEASE OF HYDROGEN PEROXIDE BY GRANULOCYTES}

\author{
AS A MODULATOR OF PLATELET REACTIONS
}

\author{
Peter H. Levine, Ronald S. Weinger, JoAnn Simon \\ Kristine L. Scoon, and Norman I. Krinsky \\ From the Blood Coagulation Laboratory and Medical Division, the Memorial \\ Hospital; the Department of Medicine, University of Massachusetts Medical \\ School, Worcester, Massachusetts 01605; the Blood Coagulation Laboratory \\ and Hematology Service, Department of Medicine, New England Medical \\ Center Hospital, and the Department of Medicine and the Department of \\ Biochemistry and Pharmacology, Tufts University School of Medicine, \\ Boston, Massachusetts 02111
}

A B S T R A C T Because of the many potent biological capabilities of the blood granulocytes, and their contact with platelets in various physiologic and pathologic states, a possible interaction between granulocytes and platelets was investigated. Platelets were purified by gel filtration and via a dialysis membrane were separated from suspensions of autologous granulocytes prepared by dextran sedimentation and resuspended in modified Tyrode's buffer. After $20 \mathrm{~min}$ at $37^{\circ} \mathrm{C}$ platelet aggregation was shown to be diminished by such exposure, as compared to the aggregation of platelets incubated with dialysates of buffer only. When granulocytes were stimulated by the addition of $1.1-\mu \mathrm{M}$ latex spheres as target particles for phagocytes, the dialysate of these cells exhibited greatly enhanced platelet-inhibitory properties. The addition of catalase to the platelets abolished the effect of exposing these cells to the dialysate of resting granulocytes and markedly inhibited the effect of exposing the platelets to the dialysate of phagocytosing granulocytes. Catalase treated with 3-amino-1,2,4triazole had no platelet-protective capacity. Purified suspensions of lymphocytes released no platelet-inhibitory principle under these experimental conditions.

Hydrogen peroxide in the dialysate of granulocytes was measured directly with an assay involving an $\mathrm{H}_{2} \mathrm{O}_{2}$ induced decrease in the fluorescence of scopoletin catalyzed by horseradish peroxidase. The dialysate of phagocytosing granulocytes contained $0.86 \pm 0.55 \mathrm{nmol}$

Received for publication 5 May 1975 and in revised form 27 October 1975.
$\mathrm{H}_{2} \mathrm{O}_{2} / 2.5 \times 10^{7}$ granulocytes when sampled at $20 \mathrm{~min}$. By an alternate measurement technique in which scopoletin and horseradish peroxidase were present in the dialysate from time zero, the mean amount of $\mathrm{H}_{2} \mathrm{O}_{2}$ in the dialysate reached $4.0 \pm 1.3 \mathrm{nmol} / 2.5 \times 10^{7}$ granulocytes at $20 \mathrm{~min}$. This discrepancy suggested the consumption of $\mathrm{H}_{2} \mathrm{O}_{2}$, possibly mediated by the granulocytes themselves. This possibility was investigated by the addition of exogenous $\mathrm{H}_{2} \mathrm{O}_{2}$ to the test system. Both granulocytes and platelets enhanced the disappearance of $\mathrm{H}_{2} \mathrm{O}_{2}$ from the dialysate, and the amount consumed was proportional to the amount of $\mathrm{H}_{2} \mathrm{O}_{2}$ added to the system.

Glucose oxidase at $12 \mathrm{M} \mathrm{U} / \mathrm{ml}$ plus glucose in excess resulted in the production of $\mathrm{H}_{2} \mathrm{O}_{2}$ at a rate and final amount comparable to that produced by phagocytosing granulocytes. This mixture, when substituted for phagocytosing granulocytes in the standard dialysis membrane experiment, induced an inhibition of platelet aggregation similar to that caused by the granulocytes.

The observation that the release of $\mathrm{H}_{2} \mathrm{O}_{2}$ by the blood granulocyte influences platelet function suggests a potential role for the granulocyte in the regulation of hemostasis or thrombosis.

\section{INTRODUCTION}

The platelet plays the central role in the initial hemostatic response and in the genesis of arterial thrombosis (1). Many studies have demonstrated interaction of the platelet with other platelets (2), with elements of 
the vessel wall (3), or with components of the blood coagulation system (4).

Although arterial thrombi are composed primarily of aggregated platelets, they are also rich in granulocytes (5-7). Despite intimate contact between these two cell types, almost nothing is known about how they interact. Given the many potent biological functions of the polymorphonuclear leukocyte $(\mathrm{PMN}),{ }^{1}$ it would be surprising if it was passive at the site of platelet reactions.

In the course of their phagocytic activity, PMN undergo significant metabolic alterations. These alterations include a respiratory burst (8), increased hexose monophosphate shunt activity (9), increased NADH oxidase activity (10), and $\mathrm{H}_{2} \mathrm{O}_{2}$ production (11). In addition to these intracellular events, phagocytosing granulocytes also release various agents, among which are $\mathrm{H}_{2} \mathrm{O}_{2}$ (12) and $\mathrm{O}_{2}^{-}$, the superoxide radical (13). Baehner et al. have demonstrated that granulocyte-released $\mathrm{H}_{2} \mathrm{O}_{2}$ has the capacity to effect neighboring cells (14). These workers mixed activated PMN with glucose-6-phosphate dehydrogenase-deficient erythrocytes and observed Heinz body formation attributable to the elaboration and release of $\mathrm{H}_{2} \mathrm{O}_{2}$ by the granulocytes.

We have previously shown that brief exposure of platelets to micromolar concentrations of $\mathrm{H}_{2} \mathrm{O}_{2}$ can cause significant inhibition of platelet function $(15,16)$. The present study deals with two questions. First, can granulocytes influence platelet function in vitro? Second, could such an interaction be mediated, at least in part, by granulocytic production of $\mathrm{H}_{2} \mathrm{O}_{2}$ ?

\section{METHODS}

Venous blood from normal individuals who had abstained from all medications, including aspirin, for at least 10 days was collected in plastic syringes and mixed immediately (5:1) with acid citrate anticoagulant (15) (one part $5 \%$ $\mathrm{Na}$ citrate and one part $2.7 \%$ citric acid plus $4 \mathrm{~g} / 100 \mathrm{ml}$ dextrose) in plastic tubes. The blood was centrifuged at $200 \mathrm{~g}$ for $10 \mathrm{~min}$ at room temperature, and the platelet-rich plasma (PRP) was removed with a siliconized Pasteur pipette.

Platelet purification. The platelets were separated from the PRP by a modification of the gel filtration technique of Tangen et al. (17). Plexiglas columns, $2.5 \times 25 \mathrm{~cm}$, were filled with Sepharose 2B (Pharmacia Fine Chemicals, Inc., Piscataway, N. J., lot 4326) so that the column bed contained $50 \mathrm{ml}$ of the Sepharose gel. The top of the column had a sample applicator whose bottom was a fine nylon mesh; the column base had coarse and fine nylon mesh. Before each experiment the column was washed three times with $100 \mathrm{ml}$ of eluting buffer. This eluting buffer was a modification of Tyrode's albumin solution and contained $129 \mathrm{mM} \mathrm{NaCl}, 9 \mathrm{mM} \mathrm{Na} \mathrm{HCO}_{3}, 6 \mathrm{mM}$ dextrose, $11 \mathrm{mM}$

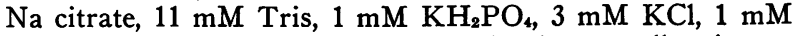
$\mathrm{MgCl}_{2}, 2 \mathrm{mM} \mathrm{CaCl}$, and $5 \mathrm{~g} / 100 \mathrm{ml}$ salt-poor albumin per

\footnotetext{
${ }^{1}$ Abbreviations used in this paper: 3-AT, 3-amino-1,2,4triazole; GFP, gel-filtered platelets; PMN, polymorphonuclear leukocytes; PRP, platelet-rich plasma.
}

$100 \mathrm{ml}$, which had previously been dialyzed against this same buffer. The final $\mathrm{pH}$ was 7.35 .

The volume of PRP applied to the top of the column varied from 6 to $10 \mathrm{ml}$. The PRP was gently layered onto the gel and the run was started. The platelet peak appeared well before the plasma and could easily be detected visually. All eluants were collected into plastic tubes, and the resultant gel-filtered platelets (GFP) were adjusted to a count of $250,000 / \mathrm{mm}^{3}$ by dilution with fresh eluant buffer. Apyrase (18) was immediately added to the GFP at a final concentration of $0.5 \mathrm{mg} / \mathrm{ml}$.

Platelet aggregation. Aggregation studies were done in the GFP by the turbidometric method of Born (19), as modified by Mustard, et al. (20). $0.4 \mathrm{ml}$ of GFP were placed in the siliconized cuvette of a Chronolog aggregometer (Chrono-Log Corp., Havertown, $\mathrm{Pa}$.) at $37^{\circ} \mathrm{C}$ and stirred at $1,200 \mathrm{rpm}$ with a Teflon-coated stir bar. The light transmittance was recorded on a moving strip chart recorder and increased as a function of the number and size of platelet aggregates. The degree of aggregation was expressed as a percent, with the light transmittance of the supernate of a sample of GFP spun on a Beckman $152 \mathrm{Mi}$ crofuge (Beckman Instruments, Inc., Spinco Div., Palo Alto, Calif.) for 2 min regarded as $100 \%$ transmission and the light transmittance of the GFP as $0 \%$ transmission.

Granulocyte suspensions. Venous blood, collected in plastic syringes and mixed immediately with acid citrate anticoagulant (as previously described) in plastic tubes, was poured into a $100-\mathrm{ml}$ plastic graduated cylinder flask. Dextran (Sigma Chemical Co., St. Louis, Mo., lot 112-1070, average mol wt 254,000 ) and $5 \mathrm{~g} / 100 \mathrm{ml}$ of $0.154 \mathrm{M} \mathrm{NaCl}$, was added at a ratio of $1 \mathrm{ml}$ of dextran solution for each $2 \mathrm{ml}$ of whole blood, as described by Babior, et al. (13). The blood was allowed to sediment for $45 \mathrm{~min}$, after which the supernate was transferred to plastic tubes and centrifuged for $15 \mathrm{~min}$ at $500 \mathrm{~g}$. The resulting leukocyte button was exposed to three parts iced distilled water for $30 \mathrm{~s}$ to lyse erythrocytes, and then one part $0.6 \mathrm{M} \mathrm{NaCl}$ was added. The suspension was spun at $500 \mathrm{~g}$ for $4 \mathrm{~min}$, and the leukocyte button was again exposed to distilled water, centrifuged, and finally washed with $0.154 \mathrm{M} \mathrm{NaCl}$. A leukocyte suspension containing 50,000 leukocytes $/ \mathrm{mm}^{3}$ was made with eluting buffer as the suspending fluid. Differential counts showed that $90-95 \%$ of these leukocytes were PMN.

Lymphocyte suspension. Blood was drawn into plastic syringes, placed into Ehrlenmeyer flasks containing glass beads, and mixed gently until defibrinogenated. Lymphocytes were isolated by the Ficol-Hypaque method of Böyum (21) and suspended in the modified Tyrode's buffer so that the final count was $40,000-50,000$ mononuclear cells $/ \mathrm{mm}^{3}$. Differential counts of these cells demonstrated them to be 95-98\% lymphocytes.

Dialysis bag experiments. A system was required to expose platelet suspensions to the products of granulocyte metabolism without direct addition of granulocytes to the platelets. This separation was achieved via a dialysis membrane. In the standard experiment leukocytes or biochemical substances were placed in the dialysis bag, which contained a final volume of $0.55 \mathrm{ml}$, and the bag was immersed in 1.0 $\mathrm{ml}$ of platelet suspension contained in a plastic test tube. After a 20 -min incubation at $37^{\circ} \mathrm{C}$ the bag was removed, and samples of the platelet suspension were studied.

Basic leukocyte-platelet protocol. Blood was drawn for leukocyte preparation at approximately $45 \mathrm{~min}$ before blood was drawn for preparation of GFP, so that all studies were performed with freshly prepared GFP.

Eight plastic tubes were divided into two sets of four 
tubes each (Fig. 1). To each tube of one set was added $0.90 \mathrm{ml}$ of the GFP plus $0.10 \mathrm{ml}$ of the stock catalase solution (see below), to inactivate any $\mathrm{H}_{2} \mathrm{O}_{2}$ formed. Dialysis bags (Fisher Scientific Co., Pittsburgh, Pa.; $1.5 \mathrm{~cm}$ inside diameter) were suspended in each tube of GFP. Bags containing $0.55 \mathrm{ml}$ buffer, in tubes 1 and 4 of each set, served as controls for bags containing $0.5 \mathrm{ml}$ leukocyte suspensions plus $0.05 \mathrm{ml}$ buffer (resting leukocytes, tube 2) and bags containing $0.5 \mathrm{ml}$ leukocyte suspension plus $0.05 \mathrm{ml}$ latex particles (activated leukocytes, tube 3 ). The ratio of latex particles to leukocytes in these studies was $1,000: 1$.

Additional experiments were run with $0.50 \mathrm{ml}$ of $\mathrm{H}_{2} \mathrm{O}_{2}$ in dialysis bags, likewise placed into $1.0 \mathrm{ml}$ GFP with or without catalase. After a 20 -min incubation at $37^{\circ} \mathrm{C}$, these bags were removed, and aggregation studies were performed on the GFP.

In each group of experiments statistical significance was determined by Student's $t$ test with paired data (22).

Generation of $\mathrm{H}_{2} \mathrm{O}$, by glucose/glucose oxidase. The method of Cohen and Hochstein (23) was used to generate various amounts of $\mathrm{H}_{2} \mathrm{O}_{2}$. Glucose oxidase (Sigma Chemical Co.), $1,200 \mathrm{U} / \mathrm{ml}$, was dialyzed overnight against distilled water and then diluted 1:2,000 with distilled water. Addition of this solution to the modified Tyrode's buffer containing $1.25 \mathrm{mM}$ glucose yielded $\mathrm{H}_{2} \mathrm{O}_{2}$, as described below.

Measurement of hydrogen peroxide. Direct measurement of $\mathrm{H}_{2} \mathrm{O}_{2}$, either produced by stimulated granulocytes or generated by a glucose/glucose oxidase system, was made by assaying the decrease in the fluorescence of scopoletin catalyzed by horseradish peroxidase. This reaction, originally described by Andreae (24), has been used by Root (25) to determine the rate of release of $\mathrm{H}_{2} \mathrm{O}_{2}$ from activated granulocytes. Fluorescence was determined in an Aminco-Bowman spectrofluorometer (American Instrument Co., Silver Spring, Md.) with an excitation wavelength of $350 \mathrm{~nm}$ and an emission wavelength of $460 \mathrm{~nm}$.

Reagents. Disodium ADP (Sigma Chemical Co.) was dissolved in barbital buffer $(\mathrm{pH} 7.35$ ) at a concentration of $10 \mathrm{mg} / 100 \mathrm{ml}$, adjusted to $\mathrm{pH} 6.8$, and frozen in $1-\mathrm{ml}$ aliquots at $-40^{\circ} \mathrm{C}$. Addition of $30 \mu \mathrm{l}$ of this solution to 0.4 $\mathrm{ml}$ of GFP yielded a final concentration of $13 \mu \mathrm{M}$ ADP.

Apyrase (Adenosine-5'-triphosphatase, Sigma Chemical Co., grade 1) had the approximate activities: 5'-ATPase, $1.58 \mathrm{U} / \mathrm{mg} ; 5^{\prime}$-ADPase, $0.57 \mathrm{U} / \mathrm{mg}$, and $5^{\prime}$-AMPase, 0.03 $\mathrm{U} / \mathrm{mg}$.

Dow latex particles obtained from Pitman-Moore Div., Dow Chemical Co., Indianapolis, Ind., having a uniform diameter of $1.10 \mu \mathrm{m}$ in a $10 \%$ solid suspension, were dialyzed against $0.9 \% \mathrm{NaCl}$ and used as target particles for phagocytosis (26).

Hydrogen peroxide, $30 \%$ solution (J. T. Baker Chemical Co., Phillipsburg, N. J.) was diluted in the modified Tyrode's buffer. This was prepared fresh before each experiment and kept at $4^{\circ} \mathrm{C}$ until used.

Purified lyophilized catalase (Worthington Biochemical Corp., Freehold, N. J., lot 5651-4), activity $3,000 \mathrm{U} / \mathrm{mg}$, was dissolved in the modified Tyrode's buffer to a concentration of $10,000 \mathrm{U} / \mathrm{ml}$. This solution was made fresh each day and when used was added to GFP to a final concentration of $1,000 \mathrm{U}$ catalase/ml GFP.

3-Amino-1,2,4-triazole (3-AT), (Sigma Chemical Co., lot 122C-0840) was dissolved in modified Tyrode's buffer to a concentration of $1 \mathrm{M}$. This solution was made fresh each day and when used was added to the GFP to a final concentration of $100 \mathrm{mM}$.

Scopoletin (Sigma Chemical Co.), $1 \mathrm{mM}$, in distilled water was stored at $4^{\circ} \mathrm{C}$. Peroxidase, type II from horse-

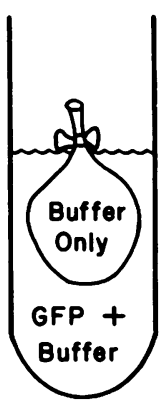

1

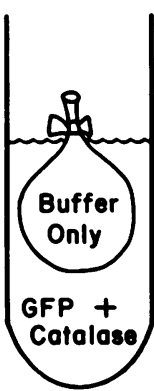

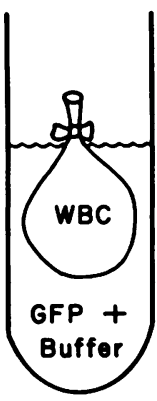

2

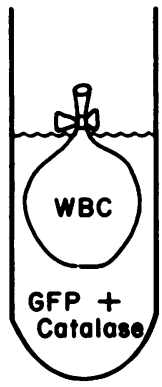

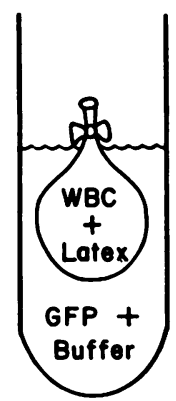

3

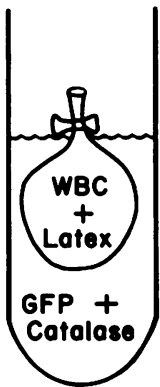

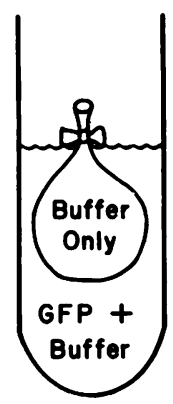

4

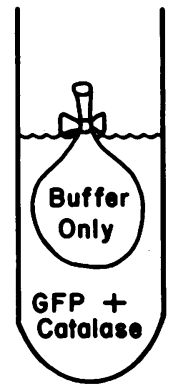

FIgURE 1 Basic granulocyte-platelet protocol. Dialysis bags containing $0.55 \mathrm{ml}$ modified Tyrode's buffer (numbers 1 and 4), $0.50 \mathrm{ml}$ granulocytes plus $0.05 \mathrm{ml}$ buffer (number 2), or $0.50 \mathrm{ml}$ granulocytes plus $0.05 \mathrm{ml}$ latex particles (number 3 ), were suspended in $1.0 \mathrm{ml}$ of autologous platelets. In the bottom set of four samples, catalase has been added to the platelet suspension. After $20 \mathrm{~min}$ at $37^{\circ} \mathrm{C}$, the bags were removed and discarded, and 0.4-ml samples of platelets were removed for aggregation studies. In each set tube 1 was the control for tube 2 , and tube 4 was the control for tube 3 . For all studies, the aggregating agent was ADP at $13 \mu \mathrm{M}$ final concentration in the platelet suspension.

radish (Sigma Chemical Co.), 100-150 purpurogallin U/ml, was made up in distilled water at a concentration of 1.0 $\mathrm{mg} / \mathrm{ml}$ and was stored at $-20^{\circ} \mathrm{C}$.

\section{RESULTS}

Effect of $\mathrm{H}_{2} \mathrm{O}_{2}$. To determine whether $\mathrm{H}_{2} \mathrm{O}_{2}$ could diffuse across a dialysis membrane and significantly alter platelet function, a series of seven experiments was performed. $\mathrm{H}_{2} \mathrm{O}_{2}$, at a concentration of $0.6 \mathrm{mM}$ in modified Tyrode's buffer, was placed in dialysis bags that were then suspended in GFP as described in Methods. After $20 \mathrm{~min}$ at $37^{\circ} \mathrm{C}$ there was a pronounced inhibition of ADP-induced aggregation of the platelets in comparison to platelets exposed to buffer only $(P<$ $0.001)$. This is shown in column A of Fig. 2 .

In a parallel set of seven experiments catalase was added to the GFP, and the above protocol was repeated. As shown in column B of Fig. 2, catalase abolished the $\mathrm{H}_{2} \mathrm{O}_{2}$ effect $(P<0.001)$. In the presence of catalase, the aggregation of platelets exposed to $\mathrm{H}_{2} \mathrm{O}_{2}$ was not 


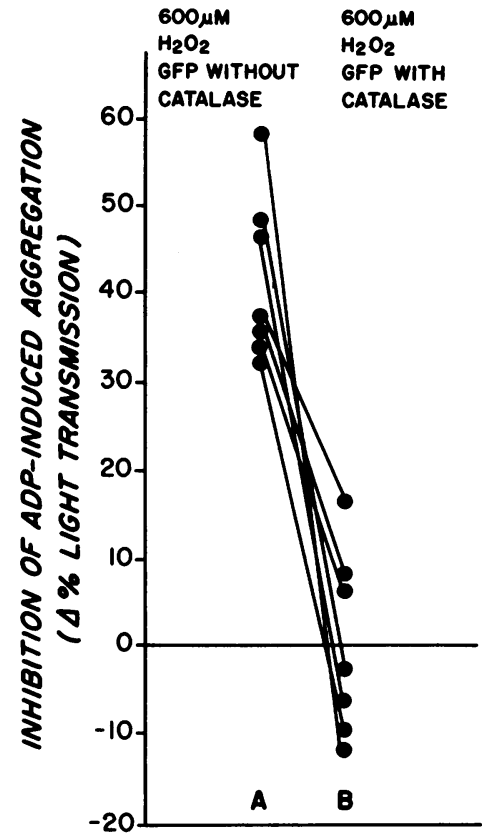

FIgURE 2 Effect of $\mathrm{H}_{2} \mathrm{O}_{2}$ on platelet function. Platelets have been exposed to dialysis bags containing buffer only or buffer plus $600 \mu \mathrm{M} \mathrm{H}_{2} \mathrm{O}_{2}$ for $20 \mathrm{~min}$ at $37^{\circ} \mathrm{C}$. Each point represents the maximum percentage of aggregation of platelets exposed to buffer minus the maximum percentage of aggregation of platelets exposed to buffer plus $\mathrm{H}_{2} \mathrm{O}_{2}$, as a measure of inhibition attributable to $\mathrm{H}_{2} \mathrm{O}_{2}$ exposure. In column $B$, catalase $(1,000 \mathrm{U} / \mathrm{ml} \mathrm{GFP})$ has been added to the GFP.

significantly different from that of platelets exposed to buffer only $(P>0.05)$.

Effect of granulocyte products. The aggregation of platelets exposed to dialysis bags containing resting granulocytes was significantly different from the aggregation of platelets incubated with bags containing buffer only. The aggregation curves obtained from a typical experiment following the protocol illustrated in Fig. 1 are shown in Fig. 3. As can be seen (Fig. 3A), resting granulocytes inhibited platelet aggregation, and the effect of phagocytosing granulocytes was much more pronounced. The addition of catalase to the platelets (Fig. 3B) largely eliminated this granulocyte-induced inhibition of platelet function.

A statistical analysis of this phenomenon in nine experiments is shown in Fig. 4. Whereas resting granulocytes produced some inhibition of aggregation (column A, Fig. 4, $P<0.05$ ), exposure of platelets to bags of activated leukocytes (Fig. 4, column B) produced a striking inhibition of aggregation, significant at the $P<0.001$ level. (In numerous trials no effect on platelet aggregation was seen when latex particles alone were placed into bags.)

Since the platelet-inhibitory effect of externally added $\mathrm{H}_{2} \mathrm{O}_{2}$ had been abolished by catalase (Fig. 2), similar experiments were performed with respect to the plateletinhibitory effects of granulocytes. In the presence of catalase, the aggregation of platelets exposed to resting granulocytes (Fig. 4, column C) was not different from the aggregation of platelets exposed to buffer only ( $P$ $>0.05)$. On the other hand catalase-treated platelets exposed to activated granulocytes (Fig. 4, column D) were significantly protected against the inhibitory effect of such exposure $(P<0.001)$. It must be noted, however, that even in the presence of catalase, there was a residual inhibition of platelet aggregation after exposure to activated granulocytes $(P<0.05)$.

The specificity of catalase as an inhibitor of the granulocyte's effect on platelets was further evaluated by use of the specific catalase antagonist (27); 3-AT. In a series of six consecutive experiments we again demonstrated that catalase diminished the effect of activated granulocytes on platelet aggregation (Fig. 5, column A). Addition of 3 -AT to the catalase-treated platelets resulted in the reappearance of inhibition of platelet aggregation after exposure to activated granulocytes (Fig. 5, column B, $(P<0.01)$.

Effect of lymphocyte products. With an identical protocol, purified lymphocytes both with and without latex spheres were studied. The platelets exposed to

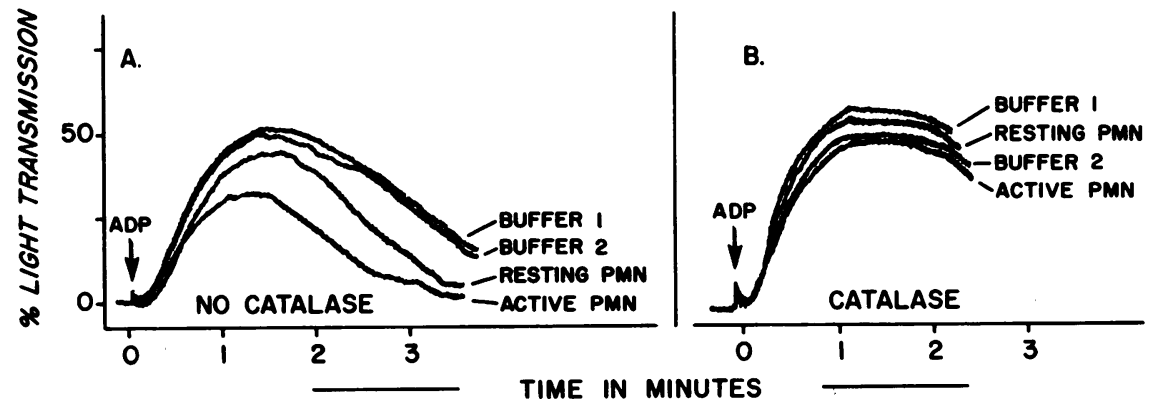

FIGURE 3 Effect of granulocyte products on platelet aggregation. A typical set of aggregation curves following the standard protocol outlined in the legend to Fig. 1 is shown. Data on nine such experiments are provided in Fig. 4. 
control dialysis bags had a maximum aggregation of $50.8 \pm 10.4 \%$ (mean $\pm \mathrm{SD}$ ) ; those exposed to lymphocyte-containing bags had maximum aggregation of 50.4 $\pm 10.8 \%$, and those exposed to lymphocytes plus latex beads had maximum aggregation of $51.2 \pm 10.0 \%$.

Quantitation of $\mathrm{H}_{2} \mathrm{O}$, production. $\mathrm{H}_{2} \mathrm{O}_{2}$ concentration was measured directly in the dialysate of stimulated granulocytes after a 20 -min incubation at $37^{\circ} \mathrm{C}$, in the absence of platelets. Scopoletin, $4 \mu \mathrm{M}$, and horseradish peroxidase, $16 \mu \mathrm{g} / \mathrm{ml}$, were added to the dialysate, and fluorescence was measured. The mean final amount of $\mathrm{H}_{2} \mathrm{O}_{2}$ found in 10 experiments was $0.86 \pm 0.55 \mathrm{nmol}$ (Fig. 6). These measurements were then repeated as a function of time as outlined below.

Scopoletin at a final concentration of $4 \mu \mathrm{M}$ was added to the granulocyte suspension in a dialysis bag just before the addition of latex particles. The bag was immediately placed into a fluorometer cuvette that contained $2.5 \mathrm{ml}$ of Krebs-Ringer bicarbonate buffer to which had been added $4 \mu \mathrm{M}$ scopoletin and horseradish

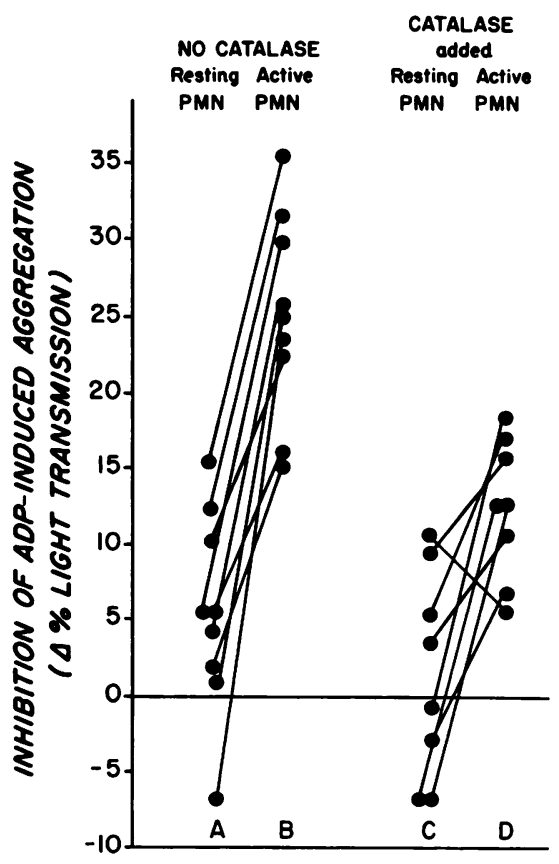

FIGURE 4 Inhibition of ADP-induced platelet aggregation after exposure to dialysis bags containing granulocytes. Protocol is outlined in legend to Fig. 1, and each point represents the maximum percentage of aggregation of platelets exposed to dialysis bags containing buffer only, minus the maximum percentage of aggregation of platelets exposed to dialysis bags containing granulocytes. The points connected by each line are the results of studies on samples of platelets and granulocytes from one donor. Note that catalase completely blocks the effect of exposing platelets to resting granulocytes (column $\mathrm{C}$ vs. column A) but does not completely block the effect of exposure of platelets to phagocytosing granulocytes (column D vs. column B, $P$ $<0.01)$.

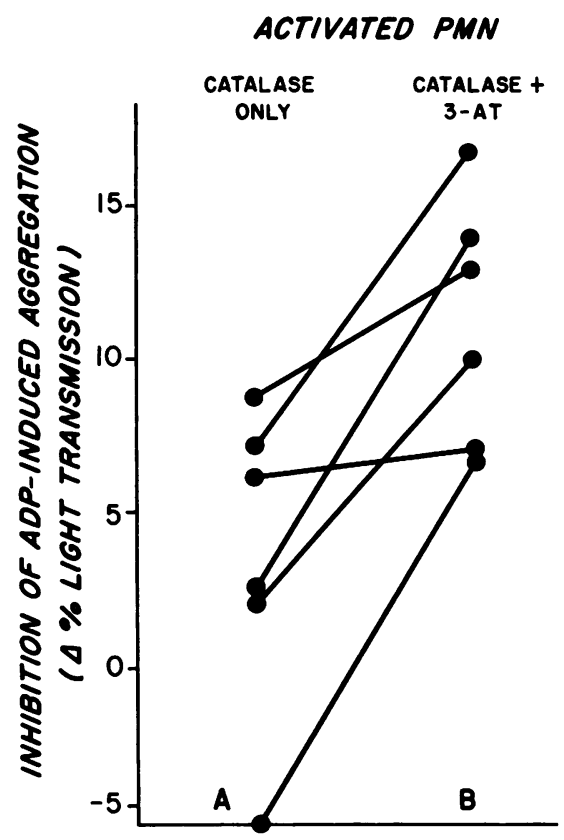

FIgURE 5 Specificity of catalase as an inhibitor of the granulocyte-platelet interaction. Six sets of studies are presented following the protocol of Fig. 4, column D, except that 3-AT was added to prevent the destruction of $\mathrm{H}_{2} \mathrm{O}_{2}$ by catalase. Column A: prevention by catalase of granulocyte-induced inhibition of platelet aggregation. Column B: addition of $0.1 \mathrm{M}$ 3-AT inhibited this protective effect of catalase. (It should be noted that in a series of six experiments, $0.1 \mathrm{M} 3-\mathrm{AT}$ itself produced mild inhibition of platelet aggregation. For this reason, the control for each point in column $\mathrm{A}$ is the aggregation of platelets plus catalase exposed to a dialysis bag of buffer only, and the control for each point in column $B$ is the aggregation of platelets plus catalase plus 3-AT exposed to a dialysis bag of buffer only.)

peroxidase, $16 \mu \mathrm{g} / \mathrm{ml}$, previously warmed to $37^{\circ} \mathrm{C}$. At regular intervals the bag was removed, and the fluorescence of the scopoletin in the dialysate was determined. The concentration of $\mathrm{H}_{2} \mathrm{O}_{2}$ in the dialysate is shown in Fig. 6. At the end of the 20-min incubation, the mean amount of $\mathrm{H}_{2} \mathrm{O}_{2}$ in the dialysate had reached $4.0 \pm 1.3$ nmol. Resting granulocytes were similarly studied, and within the limits of the sensitivity of the method no reproducible change in fluorescence could be found.

Consumption of $\mathrm{H}_{8} \mathrm{O} \&$. The experiments described in the above two paragraphs revealed a discrepancy in the amount of $\mathrm{H}_{2} \mathrm{O}_{2}$ measured in the dialysate of activated PMN. The final amount was considerably greater when scopoletin and horseradish peroxidase were present in the dialysate. This suggested that some of the $\mathrm{H}_{2} \mathrm{O}_{2}$ produced was disappearing during the course of the 20-min incubation. Could the activated leukocytes themselves be responsible for degradation of $\mathrm{H}_{2} \mathrm{O}_{2}$ ? To answer this question, activated granulocytes in dialysis bags were exposed to either buffer or $\mathrm{H}_{2} \mathrm{O}_{2}$-con- 


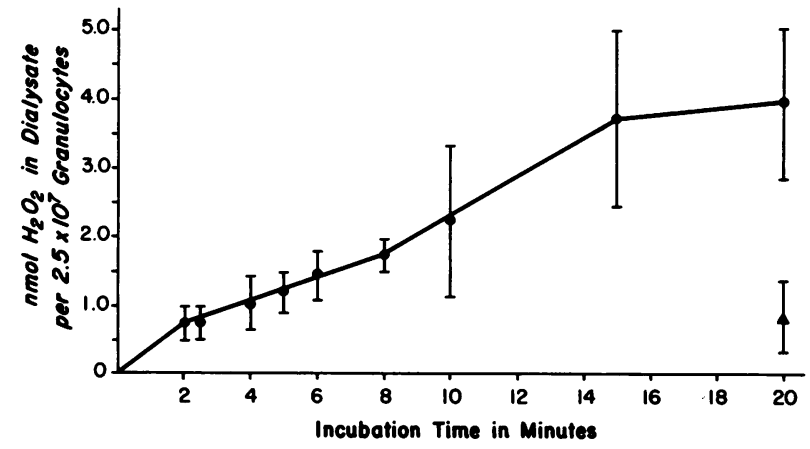

FIGURE 6 Appearance of $\mathrm{H}_{2} \mathrm{O}_{2}$ in the dialysate of phagocytosing granulocytes. A dialysis bag containing $0.5 \mathrm{ml}$ granulocyte suspension and $0.05 \mathrm{ml}$ latex particles was suspended in a fluorometer cuvette containing $2.5 \mathrm{ml}$ KrebsRinger bicarbonate buffer to which has been added $4 \mu \mathrm{M}$ scopoletin and $16 \mu \mathrm{g} / \mathrm{ml}$ horseradish peroxidase. The bag was removed at regular intervals, and fluorescence was read with an excitation wavelength of $350 \mathrm{~nm}$ and an emission wavelength of $460 \mathrm{~nm}$. Decrease of scopoletin fluorescence was proportional to $\mathrm{H}_{2} \mathrm{O}_{2}$ present. Results shown are the mean and $\mathrm{SD}$ of eight sets of duplicate determinations. The triangle represents the mean and SD of the final amount of $\mathrm{H}_{2} \mathrm{O}_{2}$ measured by another method, as follows: the dialysis bag is suspended in Krebs-Ringer bicarbonate buffer without scopoletin or horseradish peroxidase and left undisturbed for $20 \mathrm{~min}$. An aliquot of the dialysate is then removed and added to the scopoletin and horseradish peroxidase in a fluorometer cuvette. Hydrogen peroxide is measured as above.

taining solutions, and the $\mathrm{H}_{2} \mathrm{O}_{2}$ consumption was determined by the following equation: $\mathrm{H}_{2} \mathrm{O}_{2}$ consumed $=$ $\left(\mathrm{H}_{2} \mathrm{O}_{2}\right.$ added $+\mathrm{H}_{2} \mathrm{O}_{2}$ produced $)-\mathrm{H}_{2} \mathrm{O}_{2}$ observed. To control for dilution and the spontaneous disappearance of $\mathrm{H}_{2} \mathrm{O}_{2}$ at each concentration of $\mathrm{H}_{2} \mathrm{O}_{3}$ added, bags containing only buffer were handled similarly. As shown in Fig. 7, there was an apparent consumption of $\mathrm{H}_{2} \mathrm{O}_{2}$ by the phagocytosing granulocytes. The amount consumed was proportional to the amount of $\mathrm{H}_{2} \mathrm{O}_{2}$ added to the system.

Since the platelet is responsive to $\mathrm{H}_{2} \mathrm{O}_{2}$, studies were performed to determine whether this cell can also consume $\mathrm{H}_{2} \mathrm{O}_{2}$, as does the granulocyte. GFP were placed in dialysis bags at a concentration of $200,000 / \mathrm{mm}^{3}$, and the bags were suspended in fluorometer cuvettes containing Krebs-Ringer bicarbonate buffer to which varying amounts of $\mathrm{H}_{2} \mathrm{O}_{2}$ had been added. To control for dilution and spontaneous disappearance of $\mathrm{H}_{2} \mathrm{O}_{2}$, bags containing only buffer were added to cuvettes and handled similarly. The consumption of $\mathrm{H}_{2} \mathrm{O}_{2}$ mediated by platelets was determined by the following equation: $\mathrm{H}_{2} \mathrm{O}_{2}$ consumed $=\mathrm{H}_{2} \mathrm{O}_{2}$ added $-\mathrm{H}_{2} \mathrm{O}_{2}$ observed. (In a series of six experiments no $\mathrm{H}_{2} \mathrm{O}_{2}$ production could be observed from either resting or ADP-aggregated GFP.) The consumption of $\mathrm{H}_{2} \mathrm{O}_{2}$ by GFP is shown in Fig. 8 .

Use of $\mathrm{H}_{3} \mathrm{O}_{2}$-generating system. $\mathrm{H}_{2} \mathrm{O}_{2}$ was generated by the incubation of various amounts of glucose and glucose oxidase in dialysis bags, and the rate of $\mathrm{H}_{2} \mathrm{O}_{2}$ release was measured in a manner analogous to that used for intact granulocytes. By serial dilution of glucose oxidase in the presence of excess glucose a concentration was selected $(0.012 \mathrm{U} / \mathrm{ml})$ that resulted in the production of $\mathrm{H}_{2} \mathrm{O}_{2}$ at both a rate and a final concentration comparable to that produced by intact, activated granulocytes. This mixture of glucose and glucose oxidase was placed in dialysis bags and immediately suspended in tubes containing GFP. Control GFP were exposed to dialysis bags containing only buffer. As shown in Fig. 9, the exposure of GFP to bags containing glucose plus glucose oxidase resulted in a significant inhibition $(P<0.001)$ of ADP-induced platelet aggregation.

\section{DISCUSSION}

The formation of aggregates of platelets at a site of hemorrhage constitutes the primary hemostatic response (28). In addition aggregates of platelets are the main constituent of arterial thrombi (29). Therefore, factors that alter platelet function may have profound effects on hemostasis or thrombosis (30). The experiments reported here are an attempt to define a potential interaction between the platelet and the blood granulocyte, since these cells have the opportunity to make close physical contact with one another under a variety of circumstances. Our results indicate that granulocytes can release a factor or factors capable of crossing a dialysis membrane and inhibiting the platelet aggregation response.

Phagocytosing granulocytes were shown to exert a marked inhibitory effect on platelet function, while rest-

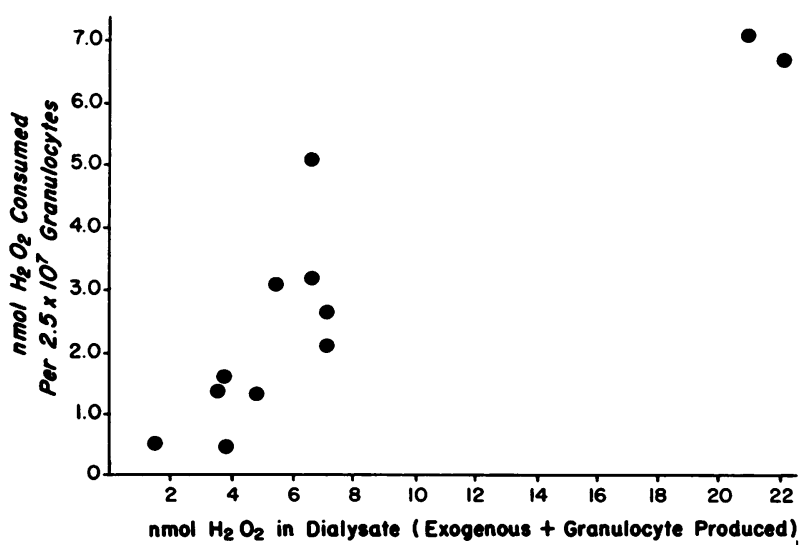

FIGURE 7 Consumption of $\mathrm{H}_{2} \mathrm{O}_{2}$ by phagocytosing granulocytes. Activated granulocytes in dialysis bags are suspended in $2.5 \mathrm{ml}$ buffer only or in $2.5 \mathrm{ml}$ buffer containing varying amounts of $\mathrm{H}_{2} \mathrm{O}_{2}$. The vertical axis shows $\mathrm{H}_{2} \mathrm{O}_{2}$ consumed, determined by the following equation: $\mathrm{H}_{2} \mathrm{O}_{2}$ consumed $=\left(\mathrm{H}_{2} \mathrm{O}_{2}\right.$ added $+\mathrm{H}_{2} \mathrm{O}_{2}$ produced by granulocytes $)$ $-\mathrm{H}_{2} \mathrm{O}_{2}$ observed. Note that consumption increased with increasing amounts of $\mathrm{H}_{2} \mathrm{O}_{2}$ present. The incubation period was $20 \mathrm{~min}$. 
ing granulocytes had a small but significant inhibitory effect. The latter may simply reflect the inability to prepare a truly "resting" population of granulocytes.

Treatment of GFP with catalase abolished the inhibitory effect of resting granulocytes, but did not completely block the inhibitory effect of activated granulocytes. The inhibitory activity attributable to activated granulocytes in the presence of catalase was still significant $(P<0.05$ when compared to GFP in the absence of catalase. The inability of catalase to completely block the effects of phagocytosing granulocytes could be due to the elaboration of additional inhibitory factors by the granulocyte. For example, stimulated granulocytes release superoxide into the surrounding medium (13). Studies are in progress to determine whether superoxide has a direct effect on platelet function. An alternative explanation for the inability of catalase to eliminate completely the inhibitory effects of phagocytosing granulocytes is that platelets may successfully compete with catalase for the available $\mathrm{H}_{2} \mathrm{O}_{2}$.

The specificity of the catalase effect was shown by the experiments with 3-AT, which specifically inhibits the degradation of $\mathrm{H}_{2} \mathrm{O}_{2}$ by catalase (27). In the presence of 3-AT there is a significant decrease in the action of catalase as an inhibitor of leukocyte-platelet interaction. This is further evidence that the inhibitory principle released is, at least in part, hydrogen peroxide.

As a further control for these experiments, GFP were exposed to dialysis bags containing autologous lymphocytes with or without latex particles. These cells

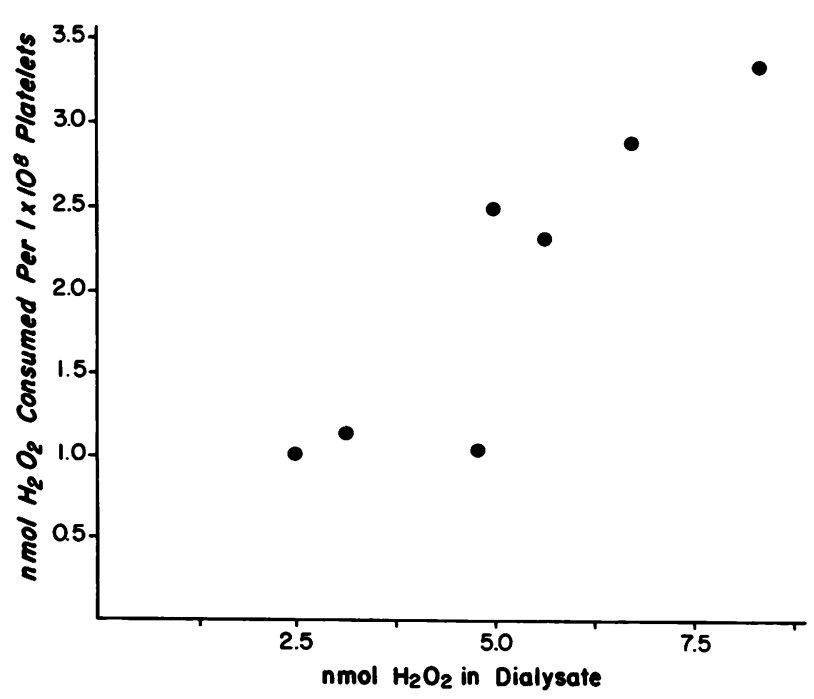

FIGURe 8 Consumption of exogenously added $\mathrm{H}_{2} \mathrm{O}_{2}$ by GFP. Experimental design is as in Fig. 7, except that 0.5 $\mathrm{ml}$ of GFP at $200,000 / \mathrm{mm}^{3}$ is substituted for granulocytes in the dialysis bags. $\mathrm{H}_{2} \mathrm{O}_{2}$ consumed $=\mathrm{H}_{2} \mathrm{O}_{2}$ exogenously added $-\mathrm{H}_{2} \mathrm{O}_{2}$ measured. (The platelets themselves released no measurable amount of $\mathrm{H}_{2} \mathrm{O}_{2}$ ).

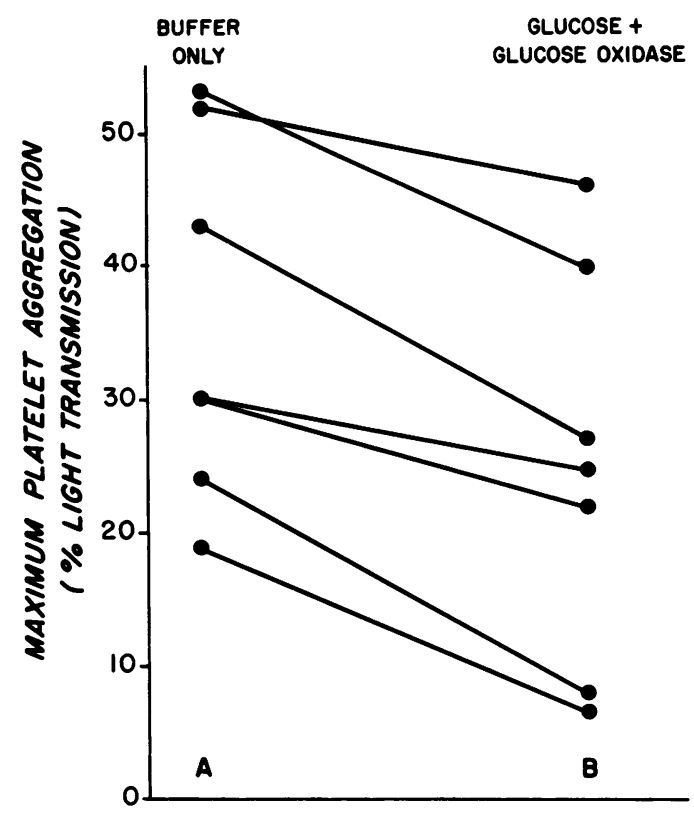

FIGURE 9 Effect of a cell-free $\mathrm{H}_{2} \mathrm{O}_{2}$-generating system on platelet function. Glucose oxidase at $0.012 \mathrm{U} / \mathrm{ml}$ and excess glucose, when placed in a dialysis bag, release $\mathrm{H}_{2} \mathrm{O}_{2}$ into the dialysate at a rate and final concentration analogous to phagocytosing granulocytes. In an experiment analogous to that in Fig. 3, aggregation after exposure to such bags (column B) was inhibited, as compared to the aggregation seen after exposure to bags of buffer only (column A vs. column B, $P<0.01)$.

did not affect platelet physiology under these experimental conditions.

If $\mathrm{H}_{2} \mathrm{O}_{2}$ is the major diffusable platelet-inhibitory factor elaborated by activated granulocytes, it should have been possible to mimic the phenomenon with a cellfree $\mathrm{H}_{2} \mathrm{O}_{2}$-generating system. This first required determination of the amount of granulocyte-produced $\mathrm{H}_{2} \mathrm{O}_{2}$ actually diffusing across the dialysis membrane. We found a mean concentration of $0.86 \mathrm{nmol} \mathrm{H}_{2} \mathrm{O}_{2}$ in the 2.5-ml dialysate of activated granulocytes after a 20 min incubation (Fig. 6). Since this was considerably lower than expected from the kinetic measurement of $\mathrm{H}_{2} \mathrm{O}_{2}$ generation by activated granulocytes (25), we determined the rate of appearance of $\mathrm{H}_{2} \mathrm{O}_{2}$ in the dialysate. Granulocyte-produced $\mathrm{H}_{2} \mathrm{O}_{2}$ diffused across the dialysis membrane at a fairly steady rate over the 20 min incubation period. This rate averaged $0.20 \mathrm{nmol} /$ $\min / 2.5 \times 10^{7}$ granulocytes and yielded a final $\mathrm{H}_{2} \mathrm{O}_{2}$ concentration of $4.0 \mathrm{nmol} / 2.5 \mathrm{ml}$ in our experimental system.

The difference between the appearance of $\mathrm{H}_{2} \mathrm{O}_{2}$ in the dialysate of stimulated PMN when monitored continuously $(4.0 \mathrm{nmol})$ and that observed by analyzing the dialysate at $20 \mathrm{~min}(0.86 \mathrm{nmol})$ indicates either degradation or consumption of the generated $\mathrm{H}_{2} \mathrm{O}_{2}$. 
Since $\mathrm{H}_{2} \mathrm{O}_{2}$ was shown to be consumed by the activated $P M N$, our value of $0.86 \mathrm{nmol}$ in the dialysate of activated $P M N$ after a 20 -min incubation reflects only that $\mathrm{H}_{2} \mathrm{O}_{2}$ generated but not subsequently consumed by the PMN.

In addition to PMN, GFP were present in the experimental set-up described in Fig. 1. These cells were also found to have the capacity to consume $\mathrm{H}_{2} \mathrm{O}_{2}$. Again, the consumption appeared to be related to the initial concentration of $\mathrm{H}_{2} \mathrm{O}_{2}$ surrounding the GFP.

Knowing the rate and amount of $\mathrm{H}_{2} \mathrm{O}_{2}$ diffusing from the dialysis bag of phagocytosing granulocytes, we could now design a simple $\mathrm{H}_{2} \mathrm{O}_{2}$-generating system of corresponding rate and concentration. An appropriate concentration of glucose-glucose oxidase was substituted for granulocytes (Fig. 9), and this mixture was capable of causing significant inhibition of platelet aggregation when $\mathrm{H}_{2} \mathrm{O}_{2}$ was generated at a rate comparable to that produced by phagocytosing granulocytes. It must be noted that this effect was less intense than that seen after exposure to intact granulocytes.

Our previous studies on the addition of single doses of $\mathrm{H}_{2} \mathrm{O}_{2}$ to platelet suspensions had led us to believe that considerably higher doses of $\mathrm{H}_{2} \mathrm{O}_{2}$ than those measured here were necessary to alter platelet function. When added as a single dose, a minimum concentration of 20 $\mu \mathrm{M} \mathrm{H}_{2} \mathrm{O}_{2}$ was necessary (15). However, when $\mathrm{H}_{2} \mathrm{O}_{2}$ was generated continuously, from either activated PMN or glucose oxidase plus glucose, much lower concentrations were capable of altering platelet function. At a rate of $\mathrm{H}_{2} \mathrm{O}_{2}$ production of $0.2 \mathrm{nmol} / \mathrm{min} / 2.5 \times 10^{7}$ $\mathrm{PMN}$, the concentration at $20 \mathrm{~min}$ would be only $1.6 \mu \mathrm{M}$ $(4.0 \mathrm{nmol} / 2.5 \mathrm{ml})$. This observation on the increased sensitivity of platelets to low levels of constantly generated $\mathrm{H}_{2} \mathrm{O}_{2}$ is in keeping with that of Cohen and Hochstein (23), who observed an increased oxidation of erythrocyte glutathione and increased osmotic fragility when these cells were exposed to a low-level, steadystate infusion of $\mathrm{H}_{2} \mathrm{O}_{2}$.

In summary, the data presented here indicate that a product or products of blood granulocytes can exert significant effects on platelet-physiology. Moreover, there is clear evidence that granulocyte-produced $\mathrm{H}_{2} \mathrm{O}_{2}$ is responsible for a significant portion of the alteration in platelet function. Biochemical alterations brought about by $\mathrm{H}_{2} \mathrm{O}_{2}$ that might explain the inhibition of platelet function include membrane lipid peroxidation (31), oxidation of free sulfhydryl groups (23), and alteration of important soluble aggregating agents released by platelets, such as prostaglandins or their precursor endoperoxides $(32,33)$. Such changes might be directly attributable to $\mathrm{H}_{2} \mathrm{O}_{2}$, or they could be brought about by the hydroxyl radical ( $\mathrm{OH} \cdot$ ) that can be formed from $\mathrm{H}_{2} \mathrm{O}_{2}$ and another granulocyte product, superoxide, in the following reaction (34): $\mathrm{H}_{2} \mathrm{O}_{2}+\mathrm{O}_{2}=$ $\rightarrow \mathrm{OH} \cdot+\mathrm{OH}^{-}+\mathrm{O}_{2}$. These various possibilities are now under investigation in our laboratory.

The incorporation of large numbers of granulocytes into freshly formed thrombi has been documented (5). In the organization phase of thrombosis, large numbers of neutrophils invade the surfaces of the thrombus closest to the blood (7). These neutrophils have been assumed to serve only a phagocytic function (6). Could such activated granulocytes, via liberation of $\mathrm{H}_{2} \mathrm{O}_{2}$ or other potent compounds, inhibit propagation at the thrombus-blood interface? Could granulocytes involved in earlier stages of the initial hemostatic response (35, 36) alter or help to regulate platelet reactions in vivo? In 1966, Harrison et al. (37) showed that varying degrees of contamination of PRP by leukocytes altered the in vitro aggregation response of the platelets. Our findings may explain their observation. Perhaps the loss of platelet function during storage of platelet concentrates is attributable in part to products the granulocytes release in these concentrates.

If the granulocyte can indeed influence the course of hemostasis and thrombosis by modulating platelet function, a new avenue of approach to the therapy of hemorrhagic and thrombotic diseases could conceivably be opened.

\section{ACKNOWLEDGMENTS}

The authors are indebted to Drs. Robert S. Schwartz and Jane F. Desforges for reviewing the manuscript, to Dr. Richard K. Root for his advice in the development of the $\mathrm{H}_{2} \mathrm{O}_{2}$ assay, and to Eileen M. O'Brien and Judy C. Hardin for their invaluable assistance in the completion of this work.

This investigation was supported in part by National Institutes of Health grant S01 RR 05598.

\section{REFERENCES}

1. Mustard, J. F., and M. A. Packham. 1970. Thromboembolism, a manifestation of the response of blood to injury. Circulation. 42: 1-21.

2. Born, G. V. R. 1972. Current ideas on the mechanism of platelet aggregation. Ann. N. Y. Acad. Sci. 201: 4-12.

3. Stemerman, M. B. 1974. Vascular intimal components: precursors of thrombosis. In Progress in Hemostasis and Thrombosis. T. H. Spaet, editor. Grune \& Stratton, Inc., New York. 2: 1-47.

4. Walsh, P. N. 1973. Platelet coagulant activities: evidence for multiple different functions of platelets in intrinsic coagulation. Ser. Haematol. 6: 579-592.

5. Henry, R. L. 1965. Leukocytes and thrombosis. Thromb. Diath. Haemorrh. 13 : 35-46.

6. Barnhart, M. I. 1964. Cellular fibrinogen. Thromb. Diath. Haemorrh. 11 (Suppl. 13) : 157-165.

7. Jorgenson, L., H. C. Rowsell, T. Hovig, and J. F. Mustard. 1967. Resolution and organization of platelet rich mural thrombi in carotid arteries of swine. Am. J. Pathol. 51 : 681-719.

8. Sbarra, A. J., and M. L. Karnovsky. 1959. The bio- 
chemical basis of phagocytosis. I. Metabolic changes during the ingestion of particles by polymorphonuclear leukocytes. J. Biol. Chem. 234: 1355-1362.

9. Baehner, R. L., N. Gilman, and M. L. Karnovsky. 1970. Respiration and glucose oxidation in human and guinea pig leukocytes. Comparative studies. J. Clin. Invest. 49: 692-700.

10. Cagan, R. H., and M. L. Karnovsky. 1964. Enzymatic basis of the respiratory stimulation during phagocytosis. Nature (Lond.). 204: 255-257.

11. Iyer, G. Y. N., M. F. Islam, and J. H. Quastel. 1961. Biochemical aspects of phagocytosis. Nature (Lond.). 192: 535-541.

12. Paul, B., and A. J. Sbarra. 1968. The role of the phagocyte in host-parasite interactions. XIII. The direct quantitative estimation of $\mathrm{H}_{2} \mathrm{O}_{2}$ in phagocytizing cells. Biochim. Biophy's. Acta. 156: 168-178.

13. Babior, B. M., R. S. Kipnes, and J. T. Curnutte. 1973. Biological defense mechanisms. The production by leukocytes of superoxide, a potential bactericidal agent. $J$. Clin. Invest. 52: 741-744.

14. Baehner, R. L., D. G. Nathan, and W. B. Castle. 1971. Oxidant injury of caucasian G6PD-deficient red blood cells by phagocytosing leukocytes during infection. $J$. Clin. Invest. 50: 2466-2473.

15. Canoso, R. T., R. Rodvien, K. L. Scoon, and P. H. Levine. 1974. Hydrogen peroxide and platelet function. Blood. 43: 645-656.

16. Rodvien, R., J. N. Lindon, and P. H. Levine. 1976. Physiology and ultrastructure of the blood platelet following exposure to hydrogen peroxide. $\mathrm{Br}$. J. Haematol. In press.

17. Tangen, O., H. J. Berman, and P. Marfey. 1971. Gel filtration: a new technique for separation of blood platelets from plasma. Thromb. Diath. Haemorrh. 25: 268-278.

18. Levy-Toledano, S. F. Rendu, E. Bodevin, and J. P. Caen. 1973. Apyrase, albumin, gammaglobulin and fibrinogen requirement for human gel-filtered platelet aggregation. In Erythrocytes, Thrombocytes, Leukocytes. E. Gerlach, editor. Georg Thieme Verlag KG, Stuttgart, W. Germany. 303-306.

19. Born, G. V. R. 1962. Aggregation of blood platelets by adenosine diphosphate and its reversal. Nature (Lond.). 194 : 927-929.

20. Mustard, J. F., T. B. Hegardt, H. C. Rowsell, and R. L. MacMillan. 1964. Effect of adenosine nucleotides on platelet aggregation and clotting time. J. Lab. Clin. Med. 64: 548-559.

21. Böyum, A. 1968. Separation of leukocytes from blood and bone marrow. Scand. J. Clin. Lab. Invest. 21: 1-11.

22. Batson, H. C. 1956. The $t$ test for paired data. In An
Introduction to Statistics in the Medical Sciences. Burgess Publishing Company, Minneapolis. 16-21.

23. Cohen, G., and P. Hochstein. 1963. Glutathione peroxidase: the primary agent for the elimination of hydrogen peroxide in erythrocytes. Biochemistry. 2: 1420-1428.

24. Andreae, W. A. 1955. A sensitive method for the estimation of hydrogen peroxide in biological materials. Nature (Lond.). 175: 859-860.

25. Root, R. K. 1975. Comparison of other defects of granulocyte oxidative killing mechanisms with chronic granulomatous disease. In The Phagocytic Cell in Host Resistance. A. J. Bellanti and D. H. Dayton, editors. Raven Press, New York. 201-219.

26. Holmes, B., A. R. Page, and R. A. Good. 1967. Studies of the metabolic activity of leukocytes from patients with a genetic abnormality of phagocyte function. $J$. Clin. Invest. 46: 1422-1432.

27. Margoliash, E., A. Novogrodsky, and A. Schejter. 1960. Irreversible reaction of 3-amino-1:2:4-triazole and related inhibitors with the protein of catalase. Biochem. $J$. 74: 339-350.

28. Packham, M. A., and J. F. Mustard. 1971. Platelet reactions. Semin. Hematol. 8: 30-64.

29. Johnson, S. A. 1971. Platelets in hemostasis and thrombosis. In The Circulating Platelet. S. A. Johnson, editor. Academic Press, Inc., New York. 355-393.

30. Mustard, J. F., R. L. Kinlough-Rathbone, C. S. P. Jenkins, and M. A. Packham. 1972. Modification of platelet function. Ann. N. Y. Acad. Sci. $201:$ 343-359.

31. Stocks, J., and T. L. Dormandy. 1971. The autoxidation of human red cell lipids induced by hydrogen peroxide. Br. J. Haematol. 20 : 95-111.

32. Silver, M. J., J. B. Smith, C. Ingerman and J. J. Kocsis. 1973. Arachidonic acid-induced human platelet aggregation and prostaglandin formation. Prostaglandins. 4: 863-875.

33. Hamberg, M., J. Svensson, and B. Samuelsson. 1974. Prostaglandin endoperoxides. A new concept concerning the mode of action and release of prostaglandins. Proc. Natl. Acad. Sci. U. S. A. 71: 3824-3828.

34. Fridovich, I. 1972. Superoxide radical and superoxide dismutase. Acc. Chem. Res. 5: 321-326.

35. Chandler, A. B. 1969. The anatomy of a thrombus. In Thrombosis. S. Sherry, K. M. Brinkhous, E. Genton, and J. M. Stengle, editors. National Academy of Sciences, Washington, D. C. 279-299.

36. Silver, M. D., W. E. Stehbens, and M. M. Silver. 1965. Platelet reaction to adenosine diphosphate in vivo. $\mathrm{Na}$ ture (Lond.). 205 : 91-92.

37. Harrison, M. J. G., P. R. Emmons, and J. R. A. Mitchell. 1966. The effect of white cells on platelet aggregation. Thromb. Diath. Haemorrh. 16: 105-121. 